\title{
ANALISIS PROSES PEMBELAJARAN MATEMATIKA BERBASIS DARING PADA MASA PANDEMI COVID-19 SISWA KELAS V SDN SUDIMARA 13 CILEDUG KOTA TANGERANG
}

\author{
Sri Melani ${ }^{1}$, Aam Amaliyah ${ }^{2}$, Candra Puspita Rini ${ }^{3}$ \\ Universitas Muhammadiyah Tangerang, Kota Tangerang \\ srimelani0299@gmail.com, aam.umt@gmail.com, candrapuspitarini@gmail.com
}

\begin{abstract}
ABSTRAK
Siswa sekolah dasar berada pada periode operasi konkret, salah satu mata pelajaran yang terkesan sulit adalah matematika. Pembelajaran matematika membutuhkan benda konkret dan penjelasan langsung dari guru. Karena adanya pandemi ini menjadikan pembelajaran harus dilakukan secara daring, termasuk pembelajaran matematika. Tujuan dari penelitian ini adalah untuk mengetahui proses pembelajaran matematika berbasis daring pada masa pandemi covid-19 siswa kelas V SDN Sudimara 13 Ciledug Kota Tangerang. Penelitian ini menggunakan pendekatan kualitatif dan metode penelitian deskriptif kualitatif dengan menggunakan teknik pengumpulan data berupa observasi, wawancara, dan dokumentasi. Teknik analisis data melalui langkah-langkah pengumpulan data, reduksi data, penyajian data dan penarikan kesimpulan. Subjek dalam penelitian ini adalah siswa kelas V SD yang berjumlah 9 siswa dan 2 guru kelas V. Hasil yang diperoleh dari penelitian ini yaitu proses pembelajaran matematika berbasis daring pada masa pandemi covid-19 siswa kelas V SDN Sudimara 13 berjalan dengan cukup baik walaupun mengalami hambatan.
\end{abstract}

Kata kunci: Pembelajaran Daring, Matematika, Covid-19

\section{ABSTRACT}

Elementary school students are in the period of concrete operations, one of the subjects that seems difficult is mathematics. Learning mathematics requires concrete objects and direct explanations from the teacher. Due to this pandemic, learning must be done online, including learning mathematics. The purpose of this study was to determine the online-based mathematics learning process during the COVID-19 pandemic for fifth grade students at SDN Sudimara 13 Ciledug, Tangerang City. This study uses a qualitative approach and descriptive qualitative research methods using data collection techniques in the form of observation, interviews, and documentation. Data analysis techniques through the steps of data collection, data reduction, data presentation and drawing conclusions. The subjects in this study consisted of 9 students of class V SD and 2 teachers of class V. The results obtained from this study were the online-based mathematics learning process during the covid-19 pandemic, fifth grade students of SDN Sudimara 13 went quite well despite experiencing obstacles.

Keywords: Online Learning, Mathematics, Covid-19

\section{PENDAHULUAN}

Pendidikan pada saat ini mengalami banyak hambatan karena adanya suatu penyakit virus menular yang sangat berbahaya yaitu Covid-19. Dengan adanya virus Covid19 ini mengakibatkan dampak buruk yang mempengaruhi dunia Pendidikan di Indonesia. Sehubungan dengan perkembangan tersebut, Menteri Pendidikan dan Kebudayaan Republik Indonesia, Nadiem Anwar Makarim mengeluarkan surat edaran Nomor 4 Tahun 2020 pada tanggal 24 Maret 2020 berisi tentang Pelaksanaan Kebijakan Pendidikan dalam Masa Darurat Peyebaran Covid-19. Dalam surat edaran dijelaskan bahwa proses pembelajaran dilaksanakan di rumah melalui daring. 


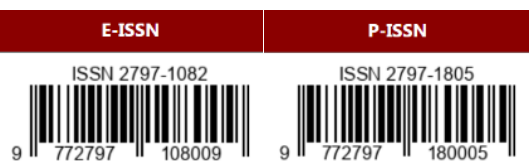

Volume 2 Nomor 1 (Desember 2021 - Februari 2022)

Pembelajaran daring adalah pembelajaran yang menggunakan jaringan internet dengan aksesibilitas, konektivitas, fleksibilitas, dan kemampuan untuk memunculkan berbagai jenis dari interaksi pembelajaran (Sadikin \& Hamidah, 2020, hal. 216). Selanjutnya pembelajaran daring (dalam jaringan) merupakan sistem pembelajaran tanpa tatap muka yang dilakukan secara langsung antara guru dan siswa tetapi dilakukan melalui online menggunakan jaringan internet (Widyastuti, 2021, hal. 23). Sejalan dengan Isman yang mengatakan bahwa pembelajaran daring merupakan pemanfaatan jaringan internet dalam proses pembelajaran. Dengan pembelajaran daring siswa memiliki keleluasaan waktu untuk belajar, dapat belajar kapanpun dan dimanapun. Siswa dapat berinteraksi dengan guru menggunakan beberapa aplikasi seperti google classroom, video converence, telepon atau live chat, zoom maupun melalui whatsapp group (Dewi, 2020, hal. 56). Sedangkan Roida (2020) mengatakan pembelajaran daring merupakan sistem pembelajaran dengan menggunakan perangkat pedagogi atau alat bantu pendidikan yang memungkinkan harus menggunakan akses internet dan teknologi informasi yang baik untuk menjadi fasilitas dalam pembentukan proses belajar dan pengetahuan melalui interaksi yang dilakukan (Salsabila, dkk, 2020, hal. 4).

Dalam pembelajaran secara daring siswa belajar menggunakan aplikasi online sehingga sanggup meningkatkan kemandirian dalam diri siswa dikala belajar. Penggunaan teknologi mempunyai pengaruh besar dalam lembaga Pendidikan. Berbagai media dapat digunakan untuk mendukung pelaksanaan pembelajaran secara daring. Seperti kelaskelas virtual menggunakan layanan Google
ClassRoom, Zoom Meeting, Google Meet, Edmodo, dan WhatsApp. Media pembelajaran adalah suatu alat bantu untuk memperjelas penyajian pesan dan informasi sehingga dapat memperjelas dan meningkatkan proses dan hasil belajar. Media pembelajaran juga dapat mengarahkan perhatian siswa sehingga dapat menimbulkan motivasi belajar yang akan berdampak pada keaktifan dan hasil belajar (Habibi, 2020, hal. 60). Pemanfaatan teknologi harus menjadi acuan bagi guru untuk mampu menghadirkan proses pembelajaran yang memberikan ruang gerak bagi siswa untuk mampu bereksplorasi seperti pembelajaran tatap muka, salah satunya pada mata pelajaran matematika.

Matematika berasal dari akar kata mathema artinya pengetahuan, mathanein artinya berpikir atau belajar. Dalam kamus besar Bahasa Indonesia diartikan matematika adalah ilmu tentang bilangan hubungan antara bilangan dan prosedur operasional yang digunakan dalam penyelesaian suatu masalah mengenai bilangan (Hamzah \& Muhlisrarini, 2014, hal. 48). Selanjutnya matematika adalah salah satu disiplin ilmu yang dapat meningkatkan kemampuan berpikir dan berargumentasi, memberikan konstribusi dalam penyelesaian masalah sehari-hari di dalam dunia kerja, serta memberikan dukungan dalam pengembangan ilmu pengetahuan dan teknologi. Bidang studi matematika merupakan salah satu komponen Pendidikan dasar dalam bidang-bidang pengajaran (Susanto, 2016, hal. 185). Sedangkan Ruseffendi (1991) berpendapat bahwa matematika adalah bahasa simbol, ilmu deduktif yang tidak menerima pembuktian secara induktif, ilmu tentang pola keteraturan, dan struktur yang terorganisasi, mulai dari unsur yang tidak didefinisikan, ke unsur yang didefinisikan, ke aksioma atau 
postulat, dan akhirnya ke dali (Heruman, 2013, hal. 1).

Pembelajaran merupakan suatu proses transfer ilmu pengetahuan dari pengajar yaitu guru kepada siswa baik di dalam lingkungan Pendidikan formal maupun non formal (Latifah \& Hamdan, 2019, hal. 2). Dalam pembelajaran terdapat tahapan pembelajaran yang pertama adalah tahap Persiapan (Perencanaan) Persiapan atau perencanaan adalah tahapan awal dalam proses perencanaan pembelajaran. Peran guru bukan hanya sebagai transformator, tapi harus berperan sebagai motivator yang membangkitkan gairah belajar, serta mendorong siswa untuk belajar dengan menggunakan berbagai variasi media, dan sumber belajar yang sesuai serta menunjang pembentukan kompetensi. Untuk membuat perencanaan yang baik dan dapat menyelenggarakan proses pembelajaran yang ideal, Hunt (1999:24) mengatakan bahwa setiap guru harus mengetahui unsur-unsur perencanaan pembelajaran yang baik, seperti: mengidentifikasi kebutuhan siswa, tujuan yang ingin dicapai, berbagai strategi/media/Teknik mengajar dan skenario yang relevan digunakan untuk mencapai tujuan, dan kriteria evaluasi (Rosnaningsih, dkk, 2019, hal. 36).

$$
\text { Tahap Pelaksanaan (Proses }
$$

Pembelajaran) Pada tahap pelaksanaan, aktivitas belajar mengajar berpedoman pada persiapan pengajaran yang dibuat. Situasi yang terdapat di dalam proses pengajaran sangat dipengaruhi oleh beberapa faktor, yaitu terdapat faktor internal atau dari diri siswa sendiri dan faktor eksternal atau dari lingkungan pembelajaran. Faktor-faktor tersebut dapat dijelaskan secara lebih rinci sebagai berikut: Faktor Siswa Menurut Hamalik (2001:99) "Siswa adalah unsur penentu dalam proses pembelajaran. siswa yang membutuhkan pengajaran, bukan guru, guru hanya berusaha memenuhi kebutuhan yang ada pada siswa”. Siswa yang belajar, karena itu maka siswa yang membutuhkan bimbingan. Faktor Guru/ Tenaga Pengajar Guru berperan dalam pertumbuhan dan perkembangan ilmu pengetahuan, keterampilan, sikap dan pandangan hidup siswa. Oleh karena itu guru harus mempunyai kompetensi profesional (penguasaan mata pelajaran), pedagogik, kepribadian dan sosial. Menurut Sopian (2016:96) "guru dalam melaksanakan tugasnya harus memiliki seperangkat kemampuan di bidang yang akan disampaikan serta harus memiliki penguasaan materi agar mudah diterima siswa yang meliputi kemampuan mengawasi, melatih, mengembangkan personalia serta keterampilan profesional dan sosial". Faktor Kurikulum Menurut Hamalik (2001:1) "Semua proses mengajar atau pengajaran, atau pelajaran senantiasa berpedoman pada kurikulum tertentu sesuai dengan tuntutan lembaga pendidikan/sekolah dan kebutuhan masyarakat serta faktor-faktor lainnya". Dari teori tersebut diketahui bahwa, bahan pelajaran sebagai isi kurikulum mengacu pada tujuan pembelajaran yang hendak dicapai. Oleh karena itu, tujuan yang hendak dicapai itu secara khusus menggambarkan perubahan tingkah laku yang diharapkan dapat dicapai siswa dalam proses belajar-mengajar. Faktor Sarana dan Prasarana Barnawi \& Arifin (2014:40) Mengatakan "sarana pendidikan adalah segala sesuatu berupa peralatan dan perlengkapan secara langsung, sedangkan prasarana pendidikan mencakup seluruh peralatan dan perlengkapan yang secara tidak langsung menunjang proses pendidikan" (Fatimah, 2021, hal. 11). 
Tahap Penilaian (Evaluasi) Penilaian dapat dilakukan dengan menggunakan tes dan non-tes dalam bentuk tertulis maupun lisan. Setiap KD dan indikator sudah mencerminkan alat penilaian yang digunakan yang meliputi ranah kognitif, afektif dan psikomotor. Halhal yang perlu diperhatikan dalam penilaian antara lain: Penilaian dilakukan untuk mengukur pencapaian kompetensi, Penilaian dilakukan berdasarkan acuan kriteria (PAK) yaitu berdasarkan apa yang dilakukan oleh siswa setelah mengikuti proses pembelajaran dan bukan untuk menentukan posisi seseorang terhadap kelompoknya, Sistem yang direncanakan adalah sistem penilaian yang berkelanjutan, berkelanjutan dalam arti indikator ditagih, kemudian hasilnya di analisis untuk menentukan Kompetensi Dasar yang telah dimiliki dan yang belum, serta untuk mengetahui kesulitan siswa., Hasil penilaian dianalisis untuk menentukan tindak lanjut, tindak lanjut berupa perbaikan proses pembelajaran berikutnya, program remedi bagi siswa yang pencapaian kompetensinya di bawah rata-rata Kriteria Ketuntasan Minimal (KKM), dan program pengayaan bagi siswa yang telah mencapai KKM, Penilaian yang dilakukan harus mengacu kepada indikator pembelajaran (Rosnaningsih, dkk, 2019, hal. 62).

\section{METODE PENELITIAN}

Dalam penelitian ini menggunakan pendekatan kualitatif dengan jenis metode penelitian deskriptif kualitatif. Hal ini dilakukan agar peneliti dapat mendeskripsikan dengan jelas dan rinci serta mendapat data yang mendalam. Subjek yang terlibat dalam penelitian ini dan menjadi sumber data utama adalah guru kelas V dan 9 siswa Kelas V SDN sudimara 13 Ciledug Kota Tangerang.
Teknik pengumpulan data dalam penelitian ini adalah observasi yang dilakukan oleh peneliti, yaitu dengan menggunakan observasi pada saat penelitian yang bertujuan untuk mengetahui segala sesuatu yang berkaitan dengan objek dari hasil pengamatan yang telah dilakukan di Sekolah SDN Sudimara 13 Ciledug Kota Tangerang, wawancara dalam penelitian ini peneliti melakukan tanya jawab dengan guru/wali kelas dan siswa kelas $\mathrm{V}$ yang berkaitan dengan bagaimana proses pembelajaran matematika siswa kelas $\mathrm{V}$ pada pembelajaran daring, dan dokumentasi untuk memperoleh data yang akurat tentang masalah-masalah yang terjadi saat proses pembelajaran matematika siswa kelas V SD pada pembelajaran daring berlangsung.

Teknik analisis data yang digunakan oleh peneliti yaitu Model analisis data kualitatif yang digunakan dalam penelitian ini adalah model Miles \& Huberman yang meliputi: reduksi data, penyajian data, dan penarikan kesimpulan.

\section{HASIL DAN PEMBAHASAN}

Berdasarkan hasil observasi, proses pembelajaran matematika siswa kelas V SDN Sudimara 13 dilakukan melalui daring. Siswa tidak lagi melakukan aktivitas belajar matematika secara tatap muka di sekolah yang mengakibatkan beberapa siswa kesulitan untuk memahami materi pembelajaran matematika dan merasa bosan dengan pembelajaran matematika yang dilakukan secara daring. Pada proses pembelajaran matematika guru menyiapkan RPP matematika daring dan menyediakan bahan ajar berupa materi pembelajaran dalam bentuk teks, link YouTube video pembelajaran dan foto materi matematika yang dikirimkan melalui WhatsApp grup kelas. Dalam proses 
pembelajaran matematika dilakukan secara daring dengan menggunakan aplikasi WhatsApp, YouTube dan Google Form.

Wawancara pada penelitian ini dilakukan melalui sambungan telepon dan dikutip dengan sedikit olahan peneliti agar dapat tersampaikan dengan baik. Berikut adalah tanggapan dari guru dan siswa kelas $\mathrm{V}$ mengenai proses pembelajaran matematika di sekolah dasar selama pandemi COVID-19.

Interviewer: Bagaimana proses pembelajaran matematika dilakukan di SDN Sudimara 13 Ciledug selama pandemic COVID-19?

Guru: Proses pembelajaran matematika saat pandemi dilakukan secara daring menggunakan aplikasi WhatsApp, Google Form, YouTube dan sesekali melakukan zoom. Dalam proses pembelajaran matematika daring guru selalu mempersiapkan media pembelajaran seperti link video pembelajaran dari YouTube yang disesuaikan dengan materi yang akan diajarkan lalu dibagikan ke grup WhatsApp dan bahan ajar yang akan digunakan seperti buku paket dan guru juga membuat RPP matematika daring. Dalam proses pembelajaran matematika daring guru menggunakan metode ceramah dan metode penugasan

R1: mengatakan bahwa proses pembelajaran matematika saat pandemi dilakukan secara daring dan merasa senang belajar matematika daring karena bisa dibantu oleh Ibundanya saat belajar matematika di rumah. Ketika proses pembelajaran matematika secara daring dilakukan R1 selalu ditemani dan dibimbing oleh Ibundanya. Dalam proses pembelajaran matematika R1 mengatakan bahwa lebih menyukai pembelajaran yang dilakukan secara tatap muka dibandingan dengan pembelajaran daring karena jika tatap muka ramai dan kalau daring merasa kesepian tidak bisa bertemu dengan teman-teman dan bermain bersama.

R2: mengatakan bahwa proses pembelajaran matematika saat pandemi dilakukan secara daring dan merasa sangat senang kalau pembelajaran matematika dilakukan secara daring karena lebih menyenangkan bisa belajar dengan melihat video pembelajaran matematika melalui Youtube yang dibagikan oleh guru dalam grup WhatsApp.

Interviewer: Apakah dampak yang dirasakan selama proses pembelajaran matematika selama pandemi COVID-19?

R3: Dampaknya merasa kurang fokus dalam memahami materi matematika melalui daring maka R3 sulit untuk mempelajari matematika. Hasil pembelajaran matematika yang dilakukan secara daring ini sangat mempengaruhi nilai R3 karena cukup rendah, penyebabnya karena R3 tidak dapat fokus belajar matematika secara daring.

R4: dampaknya R4 mengalamai Kesulitan yang dihadapi R4 saat pembelajaran matematika daring dilaksanakan yaitu R4 kesulitan dalam berhitung dan tidak bisa bertanya langsung dengan guru maka R4 merasa kurang bisa memahami materi pembelajaran matematika sendiri. R4 mengatakan bahwa lebih menyukai pembelajaran yang dilakukan secara tatap muka karena jika tatap muka bisa bertemu dengan guru dan bisa bermain dengan temanteman.

\section{Tahapan Perencanaan Pembelajaran Matematika Daring}

Berdasarkan hasil observasi dan wawancara dalam pembelajaran matematika daring pada tahap perencanaan pembelajaran ini guru mempersiapkan RPP matematika 
daring, lalu mempersiapkan media pembelajaran yang disesuaikan dengan materi yang akan dipelajari oleh siswa dan mempersiapkan bahan ajar yang akan disampaikan dalam proses pembelajaran. Hal ini sejalan dengan penelitian yang dilakukan oleh Fatimah (2021) yang menyatakan bahwa perencanaan pembelajaran daring dibuat dengan guru mempersiapkan RPP daring, membuat media pembelajaran dan mempersiapkan bahan ajar.

Berdasarkan hasil temuan observasi dan wawancara yang peneliti temukan guru sudah membuat RPP matematika daring yang digunakan untuk mengajar. Guru membuat RPP matematika daring dari awal semester dengan merujuk dari internet, dan berdiskusi dengan guru yang lain, RPP matematika daring yang dibuat guru mencangkup pendahuluan, kegiatan inti dan penutup. Selama pembelajaran matematika dilakukan secara daring guru selalu membuat RPP daring yang disusun dalam bentuk satu lembar. Guru membuat RPP daring yang disesuaikan dengan kondisi pandemi saat ini. Sebagai guru yang profesional maka sebaiknya guru harus membuat perencanaan pembelajaran dengan baik-baiknya.

Dalam mempersiapkan bahan ajar guru mempersiapkan bahan ajar berupa penugasan dari buku paket matematika siswa dan link video pembelajaran dari Youtube dan mempersiapkan materi pelajaran yang akan dijarkan kepada siswa dengan membaca materi pada buku dan juga mempelajari video yang sudah dibagikan kepada siswa, hal ini dilakukan agar saat proses pembelajaran berlangsung guru dapat menguasai semua materi pelajaran. dari hasil wawancara guru telah mempersiapkan bahan ajar yang disiapkan sebelum proses pembelajaran berlangsung. Perencanaan pembelajaran selanjutnya adalah membuat media pembelajaran, dari hasil wawancara dan observasi guru sudah mempersiapkan media pembelajaran berupa video pembelajaran dari YouTube yang sudah disesuaikan dengan materi pembelajaran matematika yang akan diajarkan. Biasanya guru akan mengirimkan link video pembelajaran tersebut ke dalam grup WhatsApp wali murid saat proses pembelajaran matematika dilaksanakan. Media pembelajaran ini sangatlah penting agar siswa dapat lebih memahami materi pelajaran dengan baik dan merasa tidak bosan belajar matematika melalui daring.

Dari hasil wawancara dan observasi dengan mengikuti langsung proses pembelajaran matematika melalui grup WhatsApp siswa di kelas tersebut sudah mampu mengoperasikan dan menggunakan media pembelajaran online seperti Handphone, membuka link pembelajaran dari Youtube dan mengisi link absensi kehadiran melalui Google Form dengan bantuan dari orang tuanya.

\section{Tahapan Pelaksanaan (Proses) Pembelajaran Matematika Daring}

Pada tahapan ini pemberian bahan pelajaran harus disesuaikan dengan urutan yang sudah diprogram dengan sistematis dan tersusun dalam tahap persiapan. Langkahlangkah dalam pelaksanaan pembelajaran meliputi yaitu: kegiatan awal, kegiatan inti, dan kegiatan akhir.

Berdasarkan hasil observasi dan wawancara dalam pelaksanaan pembelajaran matematika daring ini guru menggunakan aplikasi WhatsApp dan sesekali menggunakan zoom tetapi dalam penerapannya aplikasi zoom kurang efektif karena hanya beberapa siswa saja yang mau mengikuti pembelajaran melalui zoom. Hal 
ini sejalan dengan penelitian yang dilakukan oleh Wiryanto (2020) yang menyatakan bahwa Proses pembelajaran matematika di kelas V tidak dapat diterapkan secara efektif dan maksimal, karena beberapa kendala. Maka WhatsApp digunakan karena sebagian besar semua wali murid dan juga siswa sudah terbiasa dan mampu menggunakannya, melalui WhatsApp siswa atau wali murid dapat mengirimkan kembali tugas yang telah dikerjakan oleh anaknya.

Dalam menggunakan metode pembelajaran daring guru harus bisa menguasai teknologi dalam memberikan materi kepada siswa, dan menyusun metode pembelajaran yang membuat siswa lebih semangat dalam pembelajaran daring. Hal ini sejalan dengan penelitian yang dilakukan oleh Hermawantie, dkk (2020) yang menyatakan bahwa menggunakan metode pembelajaran, yang bertujuan supaya siswa dapat menerima materi dengan baik serta dalam proses menyampaikan materi pelajaran guru kepada siswa bisa teratur.

Berdasarkan hasil observasi dan wawancara guru sering menggunakan metode ceramah dan penugasan disaat melakukan pembelajaran melalui WhatsApp. Metode ceramah digunakan untuk menjelaskan materi yang akan dipelajari oleh siswa sehingga akan lebih mudah memahami materi pembelajaran, lalu biasanya guru akan memberikan tugas dari buku paket matematika siswa sebagai latihan dari materi yang sudah dipelajari, tetapi tugas yang diberikan tidak seperti pada pembelajaran konvensional atau tatap muka biasanya. Dalam pembelajaran daring ini siswa diberi tugas hanya beberapa soal saja, karena dalam pelaksanaan pembelajaran daring guru tidak boleh memberikan tugas terlalu banyak kepada siswa agar siswa tidak merasa terbebani.
Media pembelajaran sangat dibutuhkan dalam pembelajaran daring agar dapat membantu dan memudahkan guru dalam menyampaikan materi pelajaran dan siswa dalam memahami materi pelajaran. Dari hasil observasi dan wawancara guru sudah mempersiapkan media pembelajaran berupa video pembelajaran matematika dari Youtube, video pembelajaran yang digunakan dalam pembelajaran selalu disesuaikan dengan materi pembelajaran yang akan dipelajari oleh siswa. Video pembelajaran digunakan sebagai media pembelajaran karena guru merasa akan lebih mudah dipahami oleh siswa, karena video pembelajaran sudah tersedia penjelasan yang lengkap disertai dengan latihan soal yang bisa dipelajari oleh siswa secara jelas dan rinci.

Dari hasil observasi dan wawancara untuk ketersediaan jaringan internet di sekolah tersebut sudah mencukupi untuk pelaksanaan pembelajaran daring. Dari pihak sekolah sudah memfasilitasi para guru untuk melaksanakan pembelajaran daring dengan meminjamkan leptop dan memberikan kuota kepada setiap guru. Ketersediaan jaringan internet di rumah juga sudah mencukupi untuk melaksanakan pembelajaran daring. Ketersediaan bahan ajar dan sumber belajar lainnya seperti buku paket sudah tersedia dan sekolah juga sudah memberikan fasilitas yang dibutuhkan untuk melaksanakan pembelajaran daring. Untuk sarana dan prasarana beberapa siswa di rumah sudah cukup tersedia tetapi kebanyakan siswa tidak memiliki HandPhone sendiri, maka waktu belajar siswa sedikit terganggu karena Handphone juga digunakan orang tuanya untuk bekerja. Untuk masalah kuota internet sudah tersedia bantuan kuota internet gratis yang dibagikan oleh Kementrian Pendidikan 
dan Kebudayaan (Kemdikbud) secara gratis kepada masing-masing siswa.

Kesulitan yang dihadapi guru dalam pembelajaran daring tidak begitu mengalami kesulitan karena dalam pelaksanaan pembelajaran daring guru sudah mulai terbiasa menggunakan media elektronik dalam pembelajaran daring dan selain itu sekolah sudah mengadakan pelatihan guru kreatif sebagai bekal bagi guru dalam melaksanakan proses pembelajaran daring, sehingga guru dapat melaksanakan pembelajaran daring dengan lancar dan baik. Guru mengatakan kendala dalam pembelajaran daring lebih banyak dihadapi oleh siswa karena ada beberapa siswa yang sulit sekali untuk dihubungi dan kondisi jaringan internet siswa ada yang tidak begitu bagus karena ada siswa yang berada di kampung halamannya. Kesulitan dalam proses pembelajaran matematika yang dihadapi siswa adalah sulitnya siswa dalam memahami materi pelajaran matematika yang mereka anggap mata pelajaran matematika sulit untuk dipelajari jika tidak langsung dijelaskan oleh guru, ada beberapa siswa juga yang merasa bosan karena harus belajar matematika secara daring. Ketika siswa tidak mengerti suatu materi atau tugas matematika siswa tidak bisa bertanya secara langsung dengan guru dan guru juga tidak bisa memberikan respon yang cepat kepada siswa jika proses pembelajaran dilakukan melalui daring.

Karakteristik siswa sangat penting untuk diketahui oleh guru, karena ini dapat dijadikan sebagai bahan acuan dalam merumuskan suatu strategi pengajaran. Dari hasil wawancara yang dilakukan peneliti dengan guru kelas mengatakan bahwa karakteristik dari setiap siswa itu sangat berbeda-beda karakternya ada siswa yang sigap dan cepat mudah dalam memahami materi pembelajaran ada juga yang lambat maka harus perlu penjelasan berulang kali agar siswa tersebut dapat memahami materi pembelajaran matematika selama pembelajaran dilaksanakan melalui daring.

\section{Tahapan Penilaian (Evaluasi) Pembelajaran Matematika Daring}

Evaluasi penting dilakukan untuk mengukur tingkat pemahaman siswa. Dalam proses evaluasi pelaksanaan pembelajaran matematika secara daring ini dilakukan dengan menggunakan aplikasi WhatsApp dengan cara guru memberikan tugas kepada siswa berupa soal-soal yang terdapat di dalam buku paket matematika siswa dan setelah siswa selesai mengerjakan siswa atau wali murid mengirimkan tugas tersebut melalui chat pribadi kepada guru lalu guru akan mengirimkan kembali tugas setiap siswa yang sudah diberi nilai. Selain itu melalui WhatsApp guru dapat menyampaikan evaluasi tentang bagaimana proses pembelajaran yang telah dilakukan anaknya apakah sudah memberikan hasil yang cukup baik atau justru masih memerlukan arahan dan bimbingan yang lebih.

Dalam kesesuaian penilaian dengan Indikator pembelajaran yang terdapat dalam RPP, untuk menilai pengamatan sikap guru melihat bagaimana kedisiplinan siswa dalam mengikuti proses pembelajaran daring seperti ketepatan waktu pengumpulan tugas dan melihat bagaimana kesopanan penggunaan tata Bahasa yang digunakan oleh siswa dalam merespon pembelajaran, untuk tes pengetahuan (berupa tes tulis) guru memberikan tes berupa soal-soal yang harus dijawab oleh siswa secara tertulis. Hal ini sejalan dengan penelitian yang dilakukan oleh Hermawantie, dkk (2020) yang menyatakan 
bahwa Dalam melakukan penilaian sikap guru menilai perilaku baik dan buruk dari siswa pada proses pembelajaran, untuk penilaian pengetahuan guru melihat kemampuan siswa (menilai) disesuaikan dengan materi yang sebelumnya telah diberikan oleh guru kepada siswa dengan memberikan tes (soal) yang sudah diberi oleh guru terhadap siswa, dan yang terakhir adalah aspek penilaian keterampilan penilaian ini dilakukan dengan memperlihatkan hasil belajar siswa pada proses pembelajaran.

\section{KESIMPULAN DAN SARAN}

\section{Kesimpulan}

Berdasarkan hasil penelitian yang telah disampaikan maka dapat diambil kesimpulan bahwa dalam pelaksanaan pembelajaran matematika berbasis daring di kelas V SDN Sudimara 13 mengalami hambatan tetapi berjalan dengan cukup baik hal ini ditandai dengan guru tetap melaksanakan perencanaan pembelajaran dengan baik yaitu membuat RPP matematika daring, mempersiapkan bahan ajar seperti media pembelajaran berupa video pembelajaran. Dalam proses pembelajaran matematika daring guru mengirimkan materi dengan video pembelajaran dan soal melalui grup WhatsApp setelah itu siswa mengamati video pembelajaran matematika, metode yang digunakan guru disesuaikan dengan karakteristik siswa, guru menggunakan metode ceramah selain itu guru juga menggunakan metode penugasan untuk mengukur sejauh mana pemahaman siswa, selanjutnya untuk penilaian dan evaluasi guru menggunakan aplikasi WhatsApp, untuk mengirim kembali tugas siswa yang sudah dikoreksi. Guru juga memberikan penilaian kedisiplinan siswa dalam mengumpulkan tugas. Kesulitan yang dihadapi dalam pelaksanaan pembelajaran matematika daring yaitu adanya gangguan jaringan internet yang tidak stabil yang terkadang membuat siswa kesulitan untuk belajar. Selain itu siswa juga mengalami kesulitan dalam memahami materi pembelajaran matematika yang mereka anggap sulit jika tidak secara langsung dijelaskan oleh guru.

\section{Saran}

Berdasarkan kesimpulan yang telah diuraikan. Maka peneliti mempunyai beberapa saran untuk beberapa pihak yaitu:

a. guru

Berdasarkan hasil penelitian yang telah dilakukan, hendaknya guru dapat lebih kreatif lagi dalam memberikan materi pembelajaran secara daring, selain itu hendaknya guru lebih sering lagi berkomunikasi dengan siswa.

b. Siswa

Siswa hendaknya lebih aktif lagi dalam mengikuti pembelajaran matematika secara daring, siswa sebaiknya juga lebih aktif untuk berkomunikasi dengan guru seperti bertanya kepada guru jika ada hal yang kurang dipahami, selain itu siswa bisa lebih banyak mencari referensi pembelajaran dari berbagai media cetak maupun digital.

c. Sekolah

Dengan adanya hasil penelitian ini, maka peneliti berharap agar hendaknya dapat dijadikan sebagai masukan dan pertimbangan agar pelaksanaan pembelajaran daring dapat dilaksanakan dengan lebih baik lagi untuk kedepannya, lebih khusus selama masa pandemi covid19 ini.

d. Peneliti Selanjutnya

Semoga setelah apa yang diteliti ini dapat dilanjutkan dan dikembangkan lagi 
oleh peneliti lainnya agar pembelajaran secara daring ini dapat berlangsung dengan lebih baik lagi.

\section{DAFTAR PUSTAKA}

Dewi, Wahyu Aji Fatma. (2020, April). Dampak Covid-19 Terhadap Implementasi Pembelajaran Daring Di Sekolah Dasar. Jurnal Ilmu Pendidikan, Volume 2 Nomor 1. Retrieved from https://edukatif.org/index.php/edukati f/index

Eka Yuda Wibawa, A.. (2021). Implementasi Platform Digital Sebagai Media Pembelajaran Daring di MI Muhammadiyah PK Kartasura Pada Masa Pandemi Covid-19. Berajah Journal, 1(2), 76-84. https://doi.org/10.47353/bj.v1i2.15

Fatimah, Dewi. (2021, Januari). Analisis Pelaksanaan Pembelajaran Daring. Skripsi jurusan Pendidikan Anak Usia Dini dan Dasar Fakultas Keguruan dan Ilmu Pendidikan Universitas Jambi.

Habibi, Sahira Kartika Sari. (2020). Implementasi Pembelajaran Daring di Masa Pandemi Covid-19 Di Tingkat SD/MI. Serang: Media Madani Publisher.

Hamzah, Ali; Muhlisrarini. (2014). Perencanaan dam Strategi Pembelajaran Matematika. Jakarta: PT RajaGrafindo Persada.

Hermawantie, Firly Cahyani; dkk. (2020). Analisis

Proses Pembelajaran Matematika Berbasis Daring Pada Siswa Kelas Tinggi Sekolah Dasar. Jurnal Ilmu Pendidikan Dasar, Vol 3

No 2. Retrieved from http://journal.stkipandimatappa.ac.id/index.php/dikdas

Heruman. (2013). Model Pembelajaran Matematika di Sekolah Dasar. Bandung: PT Remaja Rosdakarya.
Latifah, Nur; Hamsanah, Hamdan Siti. (2019). Micro Teaching. Yogyakarta: Samudra Biru.

Rahmawati, R., Zuliani, R., \& Rini, C. P. (2021). Analisis Kesulitan Belajar Matematika pada Siswa Kelas V SDN Karawaci 11. NUSANTARA, 3(3), 478-488.

https://doi.org/10.36088/nusantara.v3i $\underline{3.1515}$

Rosnaningsih, Asih, dkk. (2019). Perencanaan Pembelajaran. El-Nisa Publisher \& Penerbit Pupa (Pupa Media).

Sadikin, Ali; Hamidah, Afreni;. (2020). Pembelajaran Daring di Tengah Wabah Covid-19. BIODIK, Volume 6, Nomor 02. doi: https://doi.org/10.22437/bio.v6i2.9759

Salsabila, Unik Hanifah. Dkk. (2020, Desember). Pemanfaatan Teknologi Media Pembelajaran di Masa Pandemi Covid-19. Trapsila, Vol.2 No.2.

Susanto, Ahmad. (2016). Teori Belajar \& Pembelajaran di Sekolah Dasar. Jakarta: Prenadamedia Group.

Widyastuti, Ana. (2021). Optimalisasi Pembelajaran Jarak Jauh (PJJ), Daring Luring, Bdr. Jakarta: PT Elex Media Komputindo.

Wiryanto. (2020, Mei). Proses Pembelajaran Matematika di Sekolah Dasar di Tengah Pamdemi Covid-19. Jurnal Review Pendidikan Dasar, Vol 6, No 2. 